\title{
MANAGING AGRICULTURAL ENTERPRISES WITH REGARD TO STRUCTURING THE MARKETING PROCESS
}

\author{
Levkiv Galina Yaroslavivna \\ Management Department of Economics Faculty of Education and Research Institute of Law, \\ Psychology and Economics of Lviv State University of Internal Affairs, Lviv, Ukraine
}

\author{
(C) MESTE NGO \\ JEL category: D2, 014, O3, Q19
}

\begin{abstract}
The article analyzes the process of structuring the marketing of agricultural enterprises in market conditions and its impact on the safety of the agricultural sector. After a brief analysis of recent researches, author considers some general concepts of marketing management. Detailed attention is paid to the stages of the process of marketing management and eight stages of the process of marketing management of agricultural enterprises. In the stage 1 a comparison of different types of market analysis is given. In the following stages are analyzed: selecting the market segments, choosing the concept of the agricultural enterprise, formation of marketing strategies, singling out the marketing mix, planning and development of marketing programs, the organization of marketing activities, coordination and monitoring and analysis of marketing of the enterprise. At the end of the article four key rules of marketing management for proper marketing management in advanced enterprise are specified. For proper organization of the marketing management in the developed enterprise, author suggests that four basic rules of marketing management should be used: "primary communicator", "establishing of interconnected system between market players", "integration of PR and advertising", and "marketing control and audit".
\end{abstract}

Keywwords: agricultural enterprises, market analysis, market economy, marketing management, marketing structuring, stakeholders

\section{INTRODUCTION}

A lot of scientists devoted their scientific works to the problems of formation and functioning of

The address of the author:

Levkiv Galina Yaroslavivna

拝=゙levguru81@yandex.ua marketing management of agricultural enterprises. In particular, in economic theory this aspect has been studied by: Ambler, T., Assel G., Bahiyev G. L., Voychak A. V., Golubkov E. P., Danko T. P., Dyhtl E., Kardash V. Y., Kotler F., Kretov I. I., Lamben J. J., Romanov A. N., Starostina A. O., Hershgen H., Hrutsky V. E., and 
others. Also, solving problems related to the implementation of marketing concepts in agricultural business and management of marketing processes is reflected in the works of scholars: Boyko V. I., Danilenko A. S., Zayinchkovsky A. A., Zinovchuk V. V., Imas E. V., Kamilova S. R., Kovalenko Y. S., Nelep V. M., Houdoliy L. M., Shpychak A. M., and others.

The process of marketing management of agricultural enterprises is a systematic series of actions and measures of marketing management for achieving business objectives and customer satisfaction. The constituent elements of the process of marketing management are: analysis of the market and consumer's needs, the choice of target market segments, the choice of the conceptual foundations of activity, formation of marketing strategies, allocation of the marketing mix, planning, developing of marketing program, organization of marketing activities, coordination, monitoring and analysis of marketing activity of agricultural enterprise.

\section{PROCESS OF MARKETING MANAGEMENT}

The process of marketing management of agricultural enterprises consists of several stages. This process takes place in a certain environment - marketing environment. The components of this environment are the enterprise (company), suppliers, intermediaries, clientele, competitors and contact audience.

\subsection{Stage 1}

At the stage of market and consumer needs it is necessary to perform the market analysis: its potential, capacity, market conditions, demands, consumer's behavior, the possibilities of the firm, the level of competition, etc. are being studied.

Table 1 Comparison of types of market analysis
Besides, the rate of management quality in general, marketing organization structure, the quality of all functions of marketing management, the results of marketing activities are being analyzed. This analysis involves the transformation and understanding of the information, establishing its reliability, completeness, accuracy etc. Structural map of the agricultural enterprise market shows:

1) description of the agricultural market (description of the branch, including its current size and historical growth rates, and other trends and characteristics);

2) competitive analysis (identification of their competitors at the level of product or service and market segment);

3) assessment of consumers needs (necessity of category, demand for the products at the agricultural market, the essence of buying process);

4) analysis of consumer expectations, the study of client perception (the study of the most important criteria of quality of service in terms of customer - what he expects and hopes to gain by acquiring service).

There are a variety of methodologies of market analysis: SWOT, PEST, and PESTLE - analysis. Differences in the use of these types of analysis are the following: PEST-analysis provides market research and SWOT-analysis - examines the enterprise's position in this market.

Very often such varieties of PEST-analysis are used: SLEPT analysis (involves legal factor), PESTLE analysis (political, economic, social, technological, legal, and environmental), STEEPLE analysis (social, demographic, technological, economic, environmental, political, legal, ethical factors) (see Table 1 Comparison of types of market analysis).

\begin{tabular}{|r|c|c|c|c|}
\hline \multicolumn{1}{|c|}{ № } & PEST analysis & SLEPT analysis & PESTLE analysis & STEEPLE analysis \\
\hline 1. & Politics & Politics & Politics & Socio-demographic \\
\hline 2. & Economics & Economics & Economics & Technological \\
\hline 3. & Community & Community & Community & Economic \\
\hline 4. & Technology & Technology & Technology & Natural \\
\hline 5. & - & Law & Law & Political \\
\hline 6. & - & - & Ecology & Legal \\
\hline 7. & - & - & - & Cultural \\
\hline
\end{tabular}


Let us consider SWOT and PESTLE analysis to be long-term in their application for market and organization analysis. In order to study the external microenvironment the model "Five Forces" (or "Five threats") is mostly used, and is called "5 Forces of Porter" in honor of its author Michael Porter. This model allows us to estimate five key forces that may affect the enterprise. Analysis is performed by identifying five basic competitive forces:

1) the threat of the emergence of competitors (how easy or difficult for new members is to start competing, what barriers exist),

2) the threat of the emergence of substitute products (how easy is to replace the product or service, e.g. making it cheaper),

3) market possibilities of buyers (determining the influence of buyers position, their ability to order large volumes),
4) market possibilities of suppliers (influence of the sellers position, identifying potential of suppliers, their quantity, the existence of monopoly),

5) the level of competition among existing enterprises (the presence of strong competition between the existing businesses, the presence of the dominant party or equality in strength and size. Sometimes the sixth competitive force is added: Government (Porter, 1998, p. 242).

The method of selecting the strategic directions of innovative development (innovation strategies) of the enterprise, which allows to identify and assess the competitive advantages of a certain company or activity (goods), depending on the market share that they hold, and their level of profitability, see. Fig. 1 "Selecting the strategic directions of development"

\section{Profitability, \%}

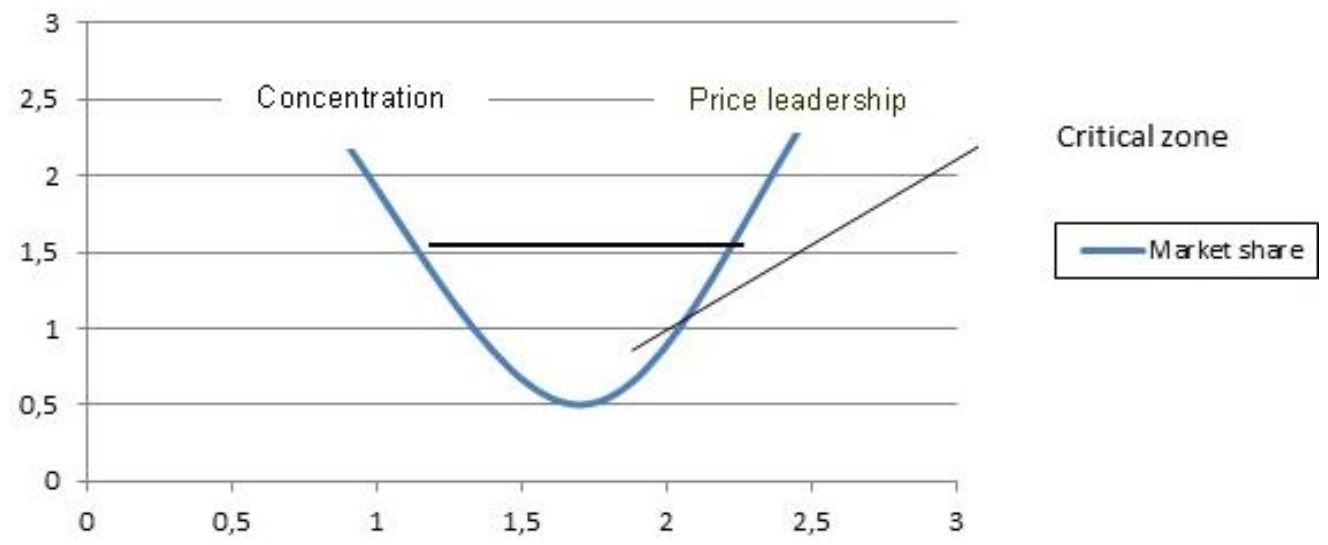

Fig. 1 Selecting the strategic directions of development (innovation strategies) of agricultural enterprises * Authoring

Table 2 Expectations of parties interested - "Stakeholders" of agricultural enterprises (Kaplan \& Norton, 1996, str. 830)

\begin{tabular}{|c|c|c|c|c|}
\hline № & Parties interested & Needs, interests & Stakeholders & Needs, interests \\
\hline 1 & \multirow{2}{*}{ Authority } & Taxes & \multirow{3}{*}{ Owners } & Dividends \\
\hline 2 & & Employment & & Capital growth \\
\hline 3 & \multirow{3}{*}{ Society } & Employment & & Security of investments \\
\hline 4 & & Environment protection & \multirow{3}{*}{ Leaders } & Authority \\
\hline 5 & & Ecology & & Remuneration \\
\hline 6 & \multirow{2}{*}{ Lenders } & Interest income & & Prestige \\
\hline 7 & & Safety of investments & \multirow{3}{*}{ Staff } & Remuneration \\
\hline 8 & \multirow{2}{*}{ Suppliers } & Long-term cooperation & & Satisfaction with work \\
\hline 9 & & Timely payment & & Safe working conditions \\
\hline 10 & \multirow{2}{*}{ Consumers } & Affordable products price & \multirow{2}{*}{$\begin{array}{l}\text { Vulnerable } \\
\text { workers }\end{array}$} & Non-discrimination \\
\hline 11 & & Quality of products & & Fair conditions of employment \\
\hline
\end{tabular}


For a detailed study of the environment of the enterprise, desires and interests of stakeholders should be considered. Accountability Scorecard (ASC), proposed by F. Nichols, aims to find the point of balancing the interests of the enterprise and other interested in its activity persons (groups of people) - stakeholders, namely, key managers and shareholders, staff, suppliers, consumers of enterprise products.

In the model ASC the enterprise and stakeholders are connected with each other by two types of relationships: contributions and incentives, while the value of incentives must exceed or at least compensate the contributions. The main objective of the model is to identify the stakeholders (the optimal number of them - from 4 to 8). Contributions and incentives should be grouped according to priorities, to determine the most important ones in the construction of strategic maps of the enterprise. Later, chosen indicators are used in the process of making strategic management decisions by managers of the enterprise. Many concepts of evaluating the efficiency of the enterprise involve the use of revenue indicators: revenue before interest payments, taxes and dividends (EBITDA), market value added (MVA), total shareholder return (TCR), economic value added (EVA) and others.

\subsection{Stage 2 - selecting the target market segments.}

Selecting target markets:

- Measurement and prediction of the market demands, identifying the market segments and substantiation of target markets.

- Information on agricultural target market limitation of the target market to an acceptable size. Many companies make the mistake of trying to appeal to a large number of target markets.

\subsection{Stage 3 - choosing the concept of the agricultural enterprise.}

The priority is given to the application of innovative concepts in synergistic use.

\subsection{Stage 4 - formation of marketing strategies}

The formating of marketing strategies means defining goals and objectives of the enterprise in the market segments according to the market situation and the possibilities of the subject which includes goals and measures. Selecting and forming strategies of differentiation and forecasting of marketing proposals; definition of significance and choice of suppliers, identifying of potential competitive advantages, choice of communicative measures for positioning the enterprise, selection of competitive differentiation tools; creating marketing strategies for market leaders, innovators, followers and owners, developing the strategies for the global market, assessment of global marketing environment, developing pricing strategies and programs: establishment and adaptation of price, selection of decisions about reactions to price changes.

\subsection{Stage 5 - singling out the marketing mix}

Model 4P - marketing mix consisting of such elements as product, price, distribution (place) and promotion (suggested by Jerry McCarthy in 1964.). In the Concept of McCarthy all four elements of the marketing mix start with the letter "P". The "4P" concept of McCarthy was first published in 1965 in the article "The Concept of the Marketing Mix" by Neil Boden. Later, as opposed to this model, the models $7 \mathrm{P}, 12 \mathrm{P}$ appeared (Otlacan, 2005, str. 34).

There is another known attempt to change the canonical "4P"formula, shifting the focus from the seller to the consumer, however, by complete abandonment of "P" - this is the concept of "4C" suggested by Bob Loteborn in 1990. The elements of the model are: Customer needs and wants; Cost to the customer; Communication exchange of information; Convenience (Otlacan, 2005, str. 42)

An alternative model of marketing mix is "SIVA", which was proposed by Chekitan S.Dev and Don E. Schultz in the Journal of Marketing Management in 2005. This model allows looking at the traditional 4P from the point of view of consumer, and includes such elements as: 
- Product - Solution (Is the solution of the found problem of meeting the customer needs appropriate?)

- Promotion - Information (Do buyers know about the decision and if so from whom they get enough information to make a decision of buying?)

- Price - Value (Value) (Does the buyer know about the value of transaction, expenses that he will bear, what will be the benefits and rewards?)

- Distribution - Access (Where can the buyer find a solution? Can they easily buy it and take delivery, near or far?)

Quite promising in application is Model 3C, which includes such components: Company, Competition and Clients.

Obviously, the model $4 \mathrm{C}$ allocates preferences of consumers as a priorities and the model $3 \mathrm{C}$ focuses on the environment of the enterprise. Formation of the marketing mix only on the basis of these models is almost impossible, as the studies of these spheres in a market analysis are already carried out, but logical integration with the marketing mix could bring positive changes in the formation of the marketing mix.

\subsection{Stage 6 - planning and development of marketing programs.}

Marketing program of the agricultural enterprise is its formation, based on strategic goals of production and sales objectives of the enterprise and ways to achieve them. The first step is to identify priority areas of marketing of the enterprise which are defined in the plan. The second step is to develop different versions of marketing programs, which should facilitate the implementation of the relevant areas of marketing. Marketing program solves three main tasks:

1) determining the volume of new production and improving old products in bulk and value terms for current and prospective period,

2) selection of the target market and final consumer considering their requirements and needs in production, and

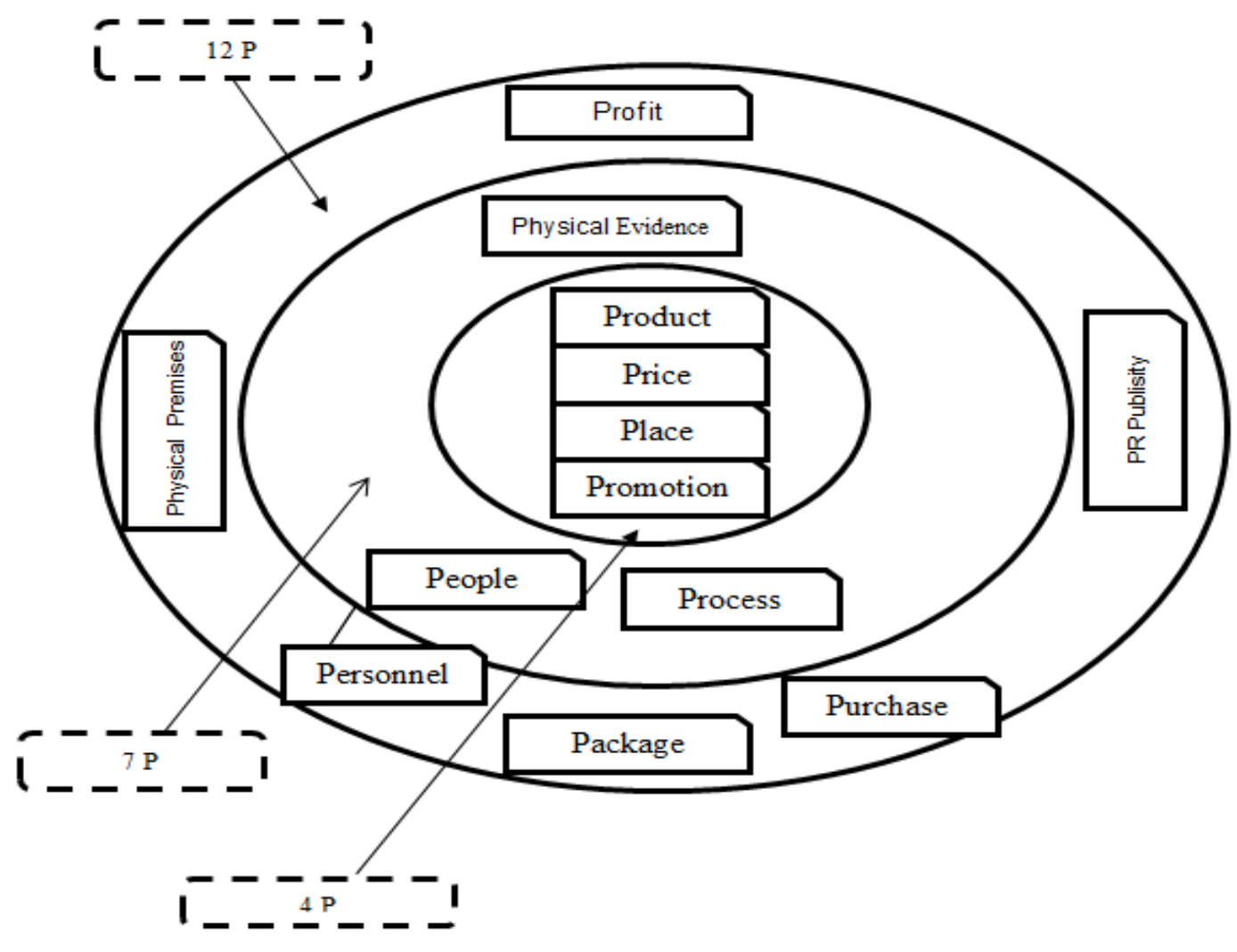

Fig. 2 Model of 4P, 7P, 12P dependence 


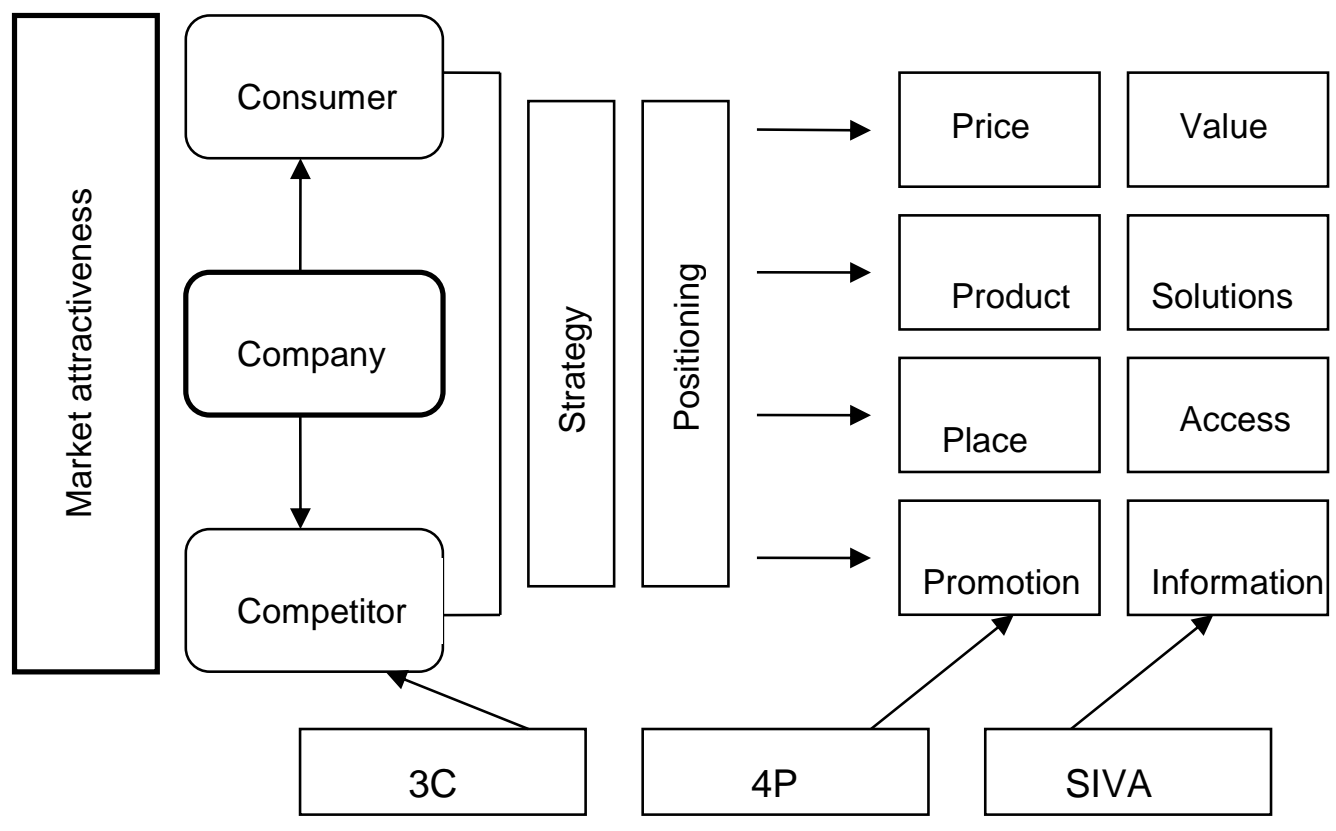

Fig. 3 Relationship of the marketing mix models

3) comparison of production costs, prices and profits for each specific product. For data processing modern information software is used including: Marketing Expert, Marketing GEO, Marketing Analytic. "Pro-Invest Consulting" has developed a set of programs - Marketing Expert, which consists of three independent programs (Marketing Expert, Marketing GEO and Marketing Analytic). (Vynogradov, 2005, str. 46)

Application of the three methods in the integrated model is presented in Figure 3.

\subsection{Stage 7 - the organization of marketing activities, coordination.}

The system of marketing services organization is very important. Such services are the prerequisite for an individual approach to the development of organizational and functional systems of marketing management. The organizational structure of the enterprise marketing activities can be defined as a set of services, departments and divisions, which include workers involved in various marketing activities.

Organizational and management structure of the marketing is aimed at: performed functions, goods and customers; regions of service. There is no universal scheme for marketing organization. Marketing departments can be created on different bases. Choice of organizational structure of marketing is conditioned by: the peculiarities of target market segments and product range of the enterprise; functional specialization of departments; distribution channel type, the presence of sales personnel; territorial factor, - since the structure of organizational flexibility of management structures, i.e. the ability to react quickly and in time to various changes is essential for the adaptation of the enterprise to the new realities of life.

\subsection{Stage 8 - monitoring and analysis of marketing of the enterprise.}

This process is carried out to verify the effectiveness of the application of marketing at the enterprise, detection of threats and their localization. Control and analysis of marketing of the enterprise is the final phase of the process of marketing management. This stage is aimed at the consideration of the nature of feedback in the activities of marketing services and includes features of analysis and diagnostics. Control of marketing activity is a means to assess the executed marketing concepts of the enterprise in set and achieved goals. The implementation of annual plans control, profitability control, 
efficiency control, strategic control, organization of audits of marketing activities is performed.

\section{THE RULES OF MARKETING MANAGEMENT}

For proper marketing management in advanced enterprise four key rules of marketing management should be used:

- the rule of "primary communicator" - the basic employee, whose purpose is to develop strategies of products promotion, marketing organization, monitoring the implementation of planned activities, etc.

- the rule of "establishing of interconnected system between market players", according to which while developing measures of marketing management it is necessary to consider partnership with suppliers, customers, internal partnership and conditional partnership with competitors.

- the rule of "integration of PR and advertising" - a combination of PR and advertising functions.

- the rule of "marketing control and audit" - in order to achieve the results of marketing management it is necessary to exercise systematic control at all stages in order to correct the marketing management process see "Fig. 4 Basic rules of marketing management".
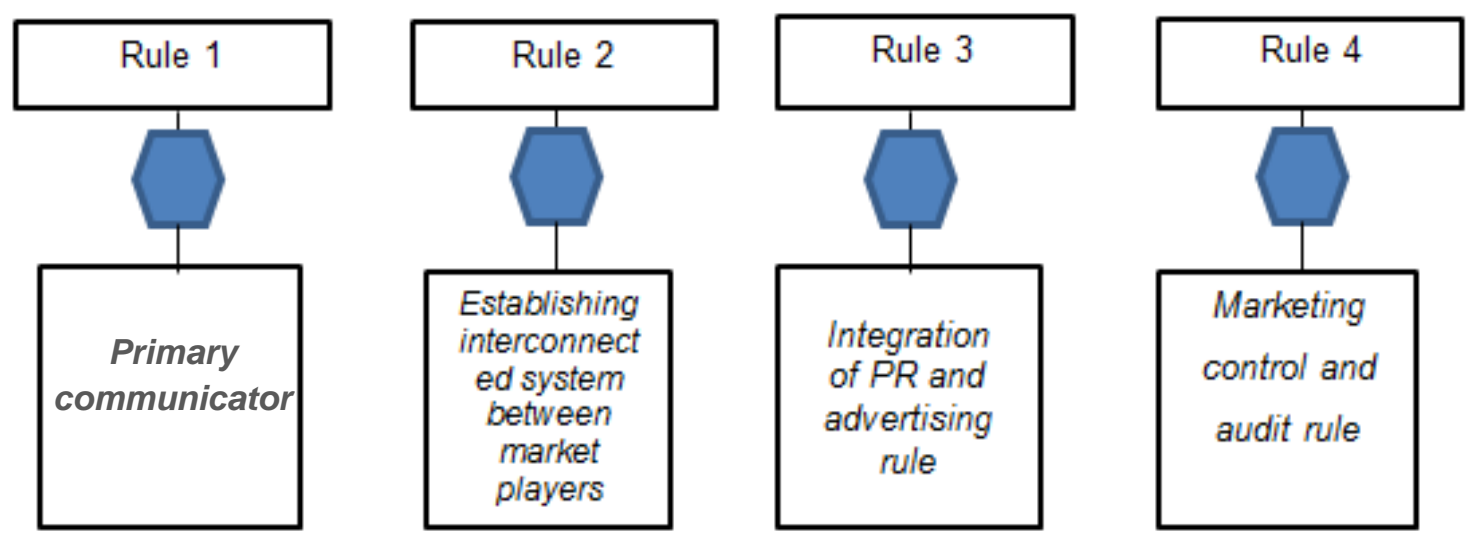

Fig. 4 Basic rules of marketing management

\section{CONCLUSIONS}

Thus, the process of marketing management of agricultural enterprises in conditions of market economy includes a set of interrelated activities on market analysis, identification of consumer needs and major market segments, the choice of conceptual frameworks of developing the marketing strategies, marketing planning, organization, coordination and control of marketing activities in the process of securing the agricultural sector.

For a detailed study of the environment of agricultural enterprises it is suggested to consider desires and interests of stakeholders, as the system performance responsibility (Accountability Scorecard - ASC) aimed to find the point of balance of the interests of the companies and their stakeholders. For marketing programs processing, modern information software, as for example: MarketingExpert, Marketing GEO, or MarketingAnalytic can be used.

On that way, the selection and differentiation strategies forming and marketing offers forecasting, the determination of significance and selection of suppliers, the identification of potential competitive advantages, the choice of communicative actions for the enterprise positioning, the choice of tools of competitive differentiation, creating marketing strategies for market leaders, development of strategies for the global market, the evaluation of the global marketing environment, development of pricing strategies and programs, they all are the main directions of marketing management. 
For proper organization of the marketing management in the developed enterprise, author suggests that four basic rules of marketing management should be used: "primary communicator", "establishing of interconnected system between market players", "integration of PR and advertising", and "marketing control and audit".

\section{Works Cited}

Bilovodska, O. (2010). Marketyngovyj menedzment. Kiev: Znannia.

Kaplan, R. S., \& Norton, D. P. (1996, Jan-Feb). Using the balanced scorecard as a strategic management system. Harvard Business Review, 75-85. Retrieved from http://hbr.org/2007/07/using-the-balanced-scorecard-as-a-strategic-management-system/ar/1

Levkiv, G. J., Miniv, R. M., \& Batjuk, B. (2011). Marketingovij menedzhment. L'viv: Spolom.

Otlacan, O. (2005, 03 25). E-Marketing Strategy: 7 Dimensions to Consider (The E-Marketing Mix). Retrieved from Ezine @rticles: http://ezinearticles.com/?e-Marketing-Strategy:-7-Dimensionsto-Consider-(the-e-Marketing-Mix)\&id=21976

Porter, M. E. (1998). Competitive Strategy: Techniques for Analyzing Industries and Competitors. Free Press.

Vynogradov, O. (2005). The use of information technologies in maintenance of the innovative activities marketing. Aktual'ni problemy ekonomiky(10 (52)), 45-52. Retrieved from http://ecoscience.net/archive2005/39--1052.html

Received for publication: 06.01.2013

Revision received: $\quad 01.03 .2013$

Accepted for publication: 29.03.2013

\section{How to cite this article?}

Style - APA Sixth Edition:

Levkiv, Y. G. (2013, 07 15). Managing agricultural enterprises with regard to structuring the marketing process. (Z. Čekerevac, Ed.) MEST Journal, 1(2), 88-95. doi:10.12709/mest.01.01.02.08

Style - Chicago Fifteenth Edition:

Levkiv, Yaroslavivna Galina. "Managing agricultural enterprises with regard to structuring the marketing process." Edited by Zoran Čekerevac. MEST Journal (MESTE) 1, no. 2 (07 2013): 88-95.

Style - GOST Name Sort:

Levkiv Yaroslavivna Galina Managing agricultural enterprises with regard to structuring the marketing process [Journal] = Marketing management on agricultural enterprises // MEST Journal / ed. Čekerevac Zoran. - Belgrade : MESTE, 07 15, 2013. - 2 : Vol. 1. - pp. 88-95. - ISSN 2334-7058 (Online); ISSN 2334-7171.

Style - Harvard Anglia:

Nakai, O., 2013. Development of beef raising product manufacturing on the innovative basis. MEST Journal, 15 07, 1(2), pp. 80-87.

Style - ISO 690 Numerical Reference:

Managing agricultural enterprises with regard to structuring the marketing process. Levkiv, Galina Yaroslavivna. [ed.] Zoran Čekerevac. 2, Belgrade : MESTE, 07 15, 2013, MEST Journal, Vol. 1, pp. 88-95. ISSN 2334-7058 (Online); ISSN 2334-7171. 